\title{
Разработка концепции преобразования глинисто-солевых отходов (шламов) после переработки К-Mg руд в комплексные удобрения пролонгированного действия, содержащие питательные компоненты (K, Mg, Са) на бесхлорной основе, минералы-мелиоранты и микроэлементы
}

\author{
А.Ф. Сметанников ${ }^{1 *}$, А.И. Косолапова ${ }^{2}$, Д.М. Оносов ${ }^{1}$, Д.С. Фомин ${ }^{2}$ \\ В.Р. Ямалтдинова ${ }^{2}$, Е.Ф. Оносова ${ }^{1}$ \\ ${ }^{1}$ ПФИЦ УрО РАН - ГИ УрО РАН, Пермь, Россия \\ ${ }^{2}$ ПНИИСХ УрО РАН, Пермь, Россия \\ *e-mail:tm_djucha@mi-perm.ru
}

В разработке концепции комплексных удобрений пролонгированного действия проявляется два основных понятия: комплексность состава удобрений и пролонгированность их действия. Комплексность можно рассматривать с двух позиций: 1) наличие питательных компонентов, мелиорирующих компонентов и микроэлементов со свойствами микроудобрений; 2) наличие собственно комплекса питательных компонентов (элементов) азота, фосфора, калия (NPK). Пролонгированность рассматривается с позиции длительности действия разовой дозы удобрений в течение нескольких сезонов, что обеспечивается наличием одного или комплекса питательных компонентов в коллекторе (минерале), характеризующихся низкой степенью растворения (поступления в почву). Этим параметрам отвечают глинисто-солевые отходы переработки $\mathrm{K}-\mathrm{Mg}$ руд (шламы), имеющие в своем составе нерастворимый в воде остаток (н.о.), включающий калиевый полевой шпат (КПШ), минералы-мелиоранты (доломит, гипс, ангидрит), микроэлементы $(\mathrm{Cu}, \mathrm{Zn}, \mathrm{Pb}, \mathrm{Co})$ и остаточные хлориды. Процессом, преобразующим отходы, является высокотемпературный обжиг (в присутствии хлоридов), приводящий к преобразованию остаточной хлоридно-калиевой части отходов, сопровождающемуся уходом хлора, вхождением калия в новообразованные калиевые минералы. Кроме того, обжиг сопровождается преобразованием сульфидов (с уходом серы) в оксидную форму, что позволяет рассматривать их как источник микроудобрений, то есть после глубокой переработки отходов формируются продукты, используемые в качестве комплексных удобрений пролонгированного действия на бесхлорной основе. Комплексность рассматривается как наличие питательных веществ, мелиорирующих веществ и микроудобрений. Испытания этого материала заключались в посадках картофеля на фоновой основе (без удобрений), посадках контрольных с применением традиционного комплекса азот-фосфор-калий (NPK) и смеси продукта глубокой переработки шламов - огарка с азотными и фосфорными добавками, то есть комплексность питательных веществ (элементов) неполная. В силу положительных результатов применения испытанного комплекса, рекомендованы эксперименты с добавками в калийные отходы, отходов обогащения фосфоритов и отходов азотного производства.

Благодарности: Работа выполнена при финансовой поддержке гранта РФФИ № 17-45-590998. 